\title{
Semiótica e interpretação do Direito ${ }^{1}$
}

\author{
Thiago Vieira Mathias de Oliveira ${ }^{2}$ \\ Profa. Dra. Marlene Kempfer Bassoli ${ }^{3}$
}

\section{Resumo}

\begin{abstract}
Relaciona os estudos sobre interpretação jurídica às investigações a respeito da ontologia e gnoseologia dos valores, da estrutura lógica da norma jurídica e da pragmática da norma jurídica. Conclui que a tarefa da interpretação jurídica é um ato complexo que deve ser praticado pelo jurista em uma postura dogmática aliada a uma postura não-dogmática, conduzindo a uma sistematização de estudos que considere os campos semânticos, sintáticos e pragmáticos da norma jurídica.
\end{abstract}

Palavras Chave: Interpretação; Valores; Normas; Signos.

\section{Introdução}

A sociedade pode ser captada como uma ordem, um sistema de interações de comportamentos mutuamente dirigidos e referidos uns aos outros, formando uma rede de relações de transmissão de mensagens de comunicação. Quando o homem se comporta, na troca dessas mensagens, cria-se uma expectativa mútua de comportamento frente ao número de possibilidades maior do que as possibilidades realizáveis ou atualizáveis. Em decorrência das desilusões que as possibilidades comunicativas provocam, a interação humana produz perturbações nos indivíduos em comunicação recíproca, que pode ser maior ou menor. Para que a sociedade pudesse se conservar, fez-se necessário uma estrutura de controle dessa contingência, realizado por meio da delimitação da atividade das pessoas que compõem a sociedade. O mecanismo em tela é a norma jurídica e a estrutura, a ordem jurídica. Nessa interferência de condutas encontra-se a raiz de toda norma jurídica.

1 Este ensaio teve por referência Trabalho de Conclusão de Curso apresentado ao Curso de Direito da Universidade Estadual de Londrina, de autoria do primeiro sob a orientação da segunda.

Aluno do 5o ano de Direito da Universidade Estadual de Londrina.

Doutora em Direito do Estado - Direito Tributário pela PUC-SP. Professora de Direito Tributário na graduação do Curso de Direito da Universidade Estadual de Londrina e dos programas de Mestrado em Direito da Universidade Estadual de Londrina e da Universidade de Marília. 


\section{Direito e interpretação}

A interpretação do Direito é tarefa incessante daquele que cuida das relações humanas postas diante de normas jurídicas. A interpretação jurídica é um ofício indissociável de qualquer sujeito que lida com o Direito e tem por objeto de estudo o Direito Positivo, conjunto de normas jurídicas válidas num determinado espaço e tempo, orientação que revela a concepção dogmática do fenômeno da sujeição do homem a um conjunto de prescrições normativas de conduta, o fenômeno jurídico. O objeto da interpretação jurídica são as normas jurídicas e a conduta humana só o é na medida em que é determinada nas normas jurídicas como pressuposto ou conseqüência ou - por outras palavras - na medida em que constitui o conteúdo das normas jurídicas ${ }^{4}$.

As normas jurídicas são bens culturais, obra da construção do homem organizado em sociedade, porque equivalem a uma alteração que o homem traça à sua própria cultura, limitando a liberdade inerente à natureza humana, o que se instrumentaliza por meio de um arcabouço formal que contém uma valoração de conduta e que visa a seu disciplinamento. Os bens culturais são apreendidos via interpretação, compreendidos num contexto impregnado de valorações pela utilização do método indutivo, porém carregado de ponderável conotação dialética ${ }^{5}$ e exprimem conteúdo que somente pode ser captado pelo homem.

Sob a perspectiva dogmática, o Direito pode ser entendido como um corpo de linguagem ${ }^{6}$ :

4 KELSEN, Hans. Teoria Pura do Direito. 6. ed. Trad. João Batista Machado. São Paulo: Martins Fontes, 1998. p. 79.

5 KELSEN, Hans. Teoria Pura do Direito. 6. ed. Trad. João Batista Machado. São Paulo: Martins Fontes, 1998. p. 79.

6 CARVALHO, Paulo de Barros. Curso de Direito Tributário. 16. ed. São Paulo: Saraiva, 2004. p. 12. 


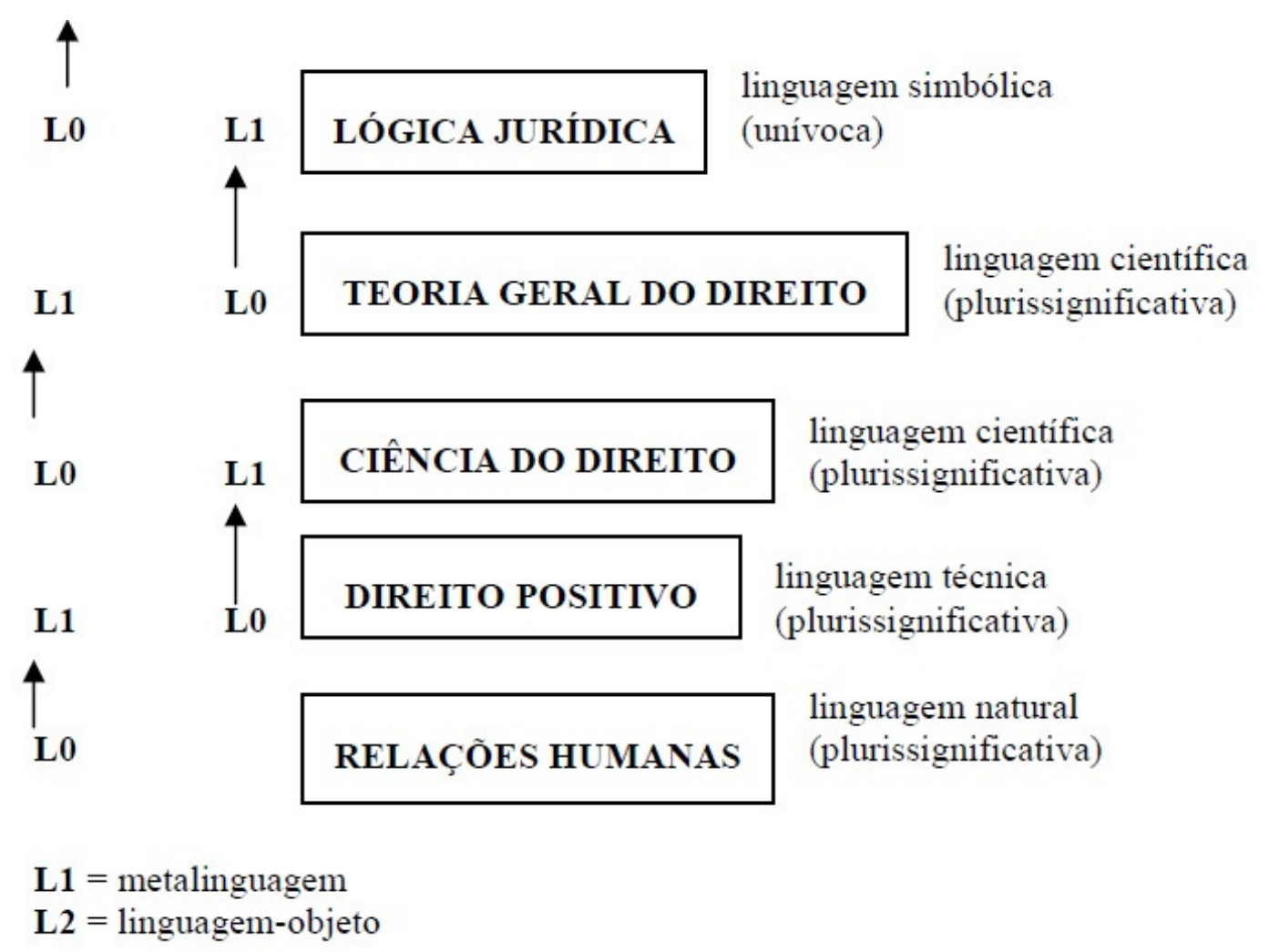

Para esta concepção, a Ciência do Direito constitui-se em um dos níveis de linguagem de que se dispõem o Direito sob o panorama dogmático. Estes níveis de linguagem se organizam em uma sobreposição de camadas lingüísticas, que se organiza de maneira tal que cada nível de linguagem desempenha ao mesmo tempo função de linguagem-objeto e de meta-linguagem em relação a outro nível de linguagem. A linguagemobjeto exerce papel funcional de objeto que é descrito. Já a metalinguagem se desenvolve de forma a descrever um objeto (a linguagem-objeto). A metalinguagem permite o controle dos processos de elucidação e de transformação das linguagens em ciência:

O sentido da distinção entre linguagem-objeto e metalinguagem é dado, segundo os lógico-positivistas, pela incapacidade das linguagens produzirem processos de autocontrole sobre a lei de sua organização lógica. Necessita-se então, da construção de um outro nível de linguagem, a partir do qual se possa fazer uma investigação problematizadora dos componentes e estruturas que se pretende analisar ${ }^{7}$.

A Ciência do Direito, correspondente à sistematização didática, técnica e metodizada do conjunto de normas jurídicas postas, tem como objeto de estudo o Direito

7 WARAT, Luiz. O Direito e sua Linguagem. 2ª versão. Porto Alegre: Sergio Antônio Fabris Editor, 1984. p. 45. 
Positivo, conjunto de normas válidas num determinado lugar e tempo. É, portanto, metalinguagem em relação ao Direito Positivo, realidade posta, que por sua vez é linguagem-objeto em relação à Ciência do Direito. Admitindo-se que as preocupações da Ciência do Direito são as de efetuar uma descrição do Direito Positivo de um país, cujas enunciações constituem um corpo lingüístico, as proposições descritivas deste Direito Positivo constituem uma metalinguagem. O discurso normativo, o Direito Positivo, objeto da reflexão científica, constitui-se, então, pela linguagem-objeto. A Ciência do Direito deve construir seu objeto sobre dados, que são expressos pela própria linguagem. A Ciência do Direito fala sobre algo que já é linguagem anteriormente à sua fala.

Já a Teoria Geral do Direito, que reúne os conceitos propedêuticos (norma jurídica, direito subjetivo, fonte jurídica, sujeito de direito etc.) comuns às especificações do Direito Positivo em ramos, é metalinguagem em relação à Ciência do Direito, que, neste nível, é linguagem-objeto em relação à Teoria Geral do Direito. Por fim, tem-se que a Lógica Jurídica, que descreve os pontos de interseção dos vários segmentos propostos pela Ciência do Direito, num estudo da estrutura da norma jurídica (fato jurídico, relação jurídica, antijuridicidade e sanção), é metalinguagem em relação à Teoria Geral do Direito, a qual desempenha função de linguagem-objeto frente à Lógica Jurídica. O que se diz numa linguagem pode ser mostrado e problematizado em uma nova metalinguagem em uma cadeia metalingüística.

A interpretação jurídica permite à Ciência do Direito ordenar de forma coerente seu objeto e delimitar conjuntos de características comuns, identificando relações interpessoais que guardam semelhança entre si, o que equivale a compor os chamados ramos do Direito. A Ciência do Direito se desenvolve necessariamente a partir da experiência das normas jurídicas positivadas, tendo como ponto de partida e balizando-se nos limites que estas estabelecem. Para se fazer Ciência do Direito, é preciso analisar o Direito posto e o encadeamento lógico entre seus elementos, já estabelecidas todas as suas significações, o que equivale a uma das etapas da interpretação jurídica.

Mas a tarefa de interpretar o Direito não se extingue aí. O objetivo maior do intérprete é a compreensão do discurso empreendido pelo Direito como o fim de decidir conflitos. A interpretação jurídica deve ser compreendida como um ato complexo que alia atitude dogmática e atitude não dogmática frente à insuficiência da Ciência Jurídica 
Dogmática para a solução dos conflitos intersubjetivos. Parte das investigações necessárias à tarefa da interpretação do Direito antecedem à própria Ciência do Direito, a qual, para sistematização do texto do Direito Positivo, exige e supõe a compreensão do conteúdos das normas em si. Apesar de Ciência do Direito e interpretação jurídica possuírem o mesmo objeto de estudo, o Direito Positivo, o ato interpretativo não se perfaz completamente com a sistematização deste e se revela uma atividade de cunho especialmente filosófico. A interpretação filosófica do Direito:

i) supera a mecanização da utilização indiscriminada a acriteriosa dos processos ou técnicas de operação da interpretação, os métodos hermenêuticos (gramatical, lógico, histórico/sociológico, teleológico/axiológico);

ii) supera uma atitude puramente cognitiva, característica de quem faz Ciência do Direito. Quem interpreta o faz com o fim de decidir conflitos intersubjetivos e tem como foco a aplicação de um significado que a norma emana a um caso particular da realidade;

iii) localiza o intérprete, quando das investigações que realiza pela prática do ato interpretativo, como construtor de sentido por meio de uma dialética intensa de argumentos formados ao longo de todo histórico desse sujeito conhecedor (précompreensão). Esta constatação influencia a concepção do que venha a ser Direito para o intérprete e, conseqüentemente, a relevância de cada método interpretativo para si, bem como sua própria postura quando da interpretação do Direito. O intérprete não deve se ater unicamente às normas jurídicas postas, mas conjugá-las à realidade que as mesmas regulam e não deve confundir suas concepções individuais com a ideologia do sistema, mas guiar-se por esta última na prática do ato interpretativo.

\section{0 ângulo semiótico da interpretação do direito}

O fenômeno jurídico sob a perspectiva dogmática tem um sentido comunicacional porque se exterioriza pela linguagem das normas jurídicas, expressões de comunicação verbal traduzidas em signos lingüísticos, as quais querem a comunicação de uma mensagem, por isso se constitui em discursos. Este não é seu sentido único, mas o sentido de, considerando o Direito como sistema de normas jurídicas, detectar a necessidade, para sua própria existência, da linguagem, que é a forma como elas são expressas. O signo, como menor unidade de um sistema lingüístico, está presente em qualquer meio de comunicação, 
não somente os sistemas comunicacionais escritos, que é o caso do sistema normativo. 0 signo é uma entidade lógica dotada de suporte físico correspondente à matéria concreta pela qual se exterioriza, um significado, que é o seu equivalente no mundo exterior e uma significação, que é a idéia ou noção que se elabora mentalmente do objeto representado.

Quanto ao significado, tomando o Direito como um corpo de linguagem, este não se restringe ao texto da lei, mas a todo estudo que tem por temática o fenômeno jurídico exteriorizado por normas jurídicas que se constitui de signos, os quais se prestam a empreender certa comunicação entre os indivíduos que às normas se submetem.

A necessidade de não olvidar a realidade posta quando da interpretação do Direito remete ao problema da decidibilidade de conflitos intersubjetivos que também (mas não unicamente) reside na norma jurídica, pois esta foi eleita pelo homem como instrumento capaz de fazê-lo. Por isso as diárias solicitações ao aplicador do Direito para que coloque fim aos conflitos humanos traduz-se em problemas de ordem semântica, sintática e pragmática, eis que estes são os aspectos, segundo uma perspectiva semiótica de análise da norma jurídica, constituída de signos. Interpretar sem se preocupar com essa tríade revela-se uma empreitada inconsistente, pois se investe contra o problema a ser solucionado sem se enfrentar suas verdadeiras causas.

Dessa forma, os signos lingüísticos, como menor unidade de qualquer sistema de linguagem, correspondem à base do trabalho da interpretação jurídica, que tem por objeto as expressões do Direito, escritas e explicitadas em signos. Trilhando a linha já anteriormente estabelecida de compreender a interpretação jurídica como um ato complexo, exercido mediante uma atitude não exclusivamente dogmática, mas especialmente de cunho filosófico, abandona-se a visão estanque de um modelo teórico para a interpretação, passando-se a utilizar o parecer de outras ciências para a composição do ato interpretativo. No contexto da constituição do Direito em um corpo de linguagem, a Semiótica Jurídica se apresenta como uma dessas ciências porque interpretar é atribuir um certo sentido a um signo que provém de um emissor (no caso da lei - o legislador) e dirige-se aos receptores (os indivíduos subordinados ao ordenamento jurídico), veiculando uma informação, empreendendo uma comunicação: 
partindo de fórmulas lingüísticas contidas nos atos normativos, alcançamos a determinação de seu conteúdo normativo: caminhamos dos significantes (os enunciados) aos significados ${ }^{8}$.

A semiótica jurídica percebe na estruturação ligüístico-formal da norma jurídica a produção e a apresentação do fenômeno jurídico na forma de signos. O ato complexo da interpretação jurídica que tem como objeto o Direito Positivo propõe uma postura filosófica para a interpretação do Direito que considere os campos semântico, sintático e pragmático da norma jurídica, como se dá em qualquer na análise de textos sob a perspectiva da semiótica.

Considerar a interpretação a determinação do sentido e alcance das expressões jurídicas ${ }^{9}$, restringe a interpretação à busca de clareza no encadeamento das diversas expressões do Direito (leis), da precisão na significação dos signos que formam essas expressões e da extensão das leis, ao se verificar para quais elementos da realidade o conteúdo da lei aponta a partir de seus termos abstratos e gerais em direção a fatos concretos (não hipotéticos) e particulares (com sujeitos determinados). Estes exercícios retratam apenas a interpretação em sentido estrito, somente o ato cognitivo, separando interpretação em sentido estrito da aplicação do Direito e não considerando este último "momento" como integrante do ato interpretativo como um todo.

Além disso, o apenas o momento cognitivo da interpretação leva em conta investigações de cunho sintático e semântico, mas não observa a investigação de cunho pragmático. O sujeito-intérprete deve interpretar para aplicar o direito, deve ter como objetivo final de sua atividade um ato decisório de escolher qual dentre as várias interpretações possíveis é a mais adequada para solucionar um conflito intersubjetivo. Esta é uma tarefa de cunho eminentemente pragmático. Sob o ângulo da semiótica, interpretar é selecionar possibilidades comunicativas da complexidade discursiva ${ }^{10}$. Para a semiótica, a interpretação seria um ato integrante de um processo de formação de um discurso que tem como objetivo a solução de conflitos, atribuindo um certo sentido a um signo que provém de

8 ZABREBELSK, Gustavo. Manuale di Diritto Constitucionale - I - Il Sistema delle Fonte Del Diritto.Torino: reimpressão UTED, 1990 apud GRAU, Eros Roberto, Ensaio e Discurso sobre a Interpretação/Aplicação do Direito. 3. ed. São Paulo: Malheiros. 2005. p. 77

9 MAXIMILIANO, Carlos. Hermenêutica e Aplicação do Direito. 19. ed. Rio de Janeiro: Forense, 2001. p. 1.

10 FERRAZ JR. Tércio Sampaio. Introdução ao estudo do direito: técnica, decisão, dominação. 3. ed. São Paulo: Atlas, 2001. p. 256. 
um emissor (lei/ legislador) e se dirige aos receptores (órgãos do Estado e os indivíduos subordinados às prescrições do ordenamento jurídico), veiculando uma informação.

O estudo da interpretação jurídica sob a perspectiva dos planos semântico, sintático e pragmático conduz o intérprete à tomada de postura dogmática aliada a uma postura nãodogmática. A primeira postura está comprometida diretamente com os conflitos jurídicos e que põe fim a divergências decorrentes das relações intersubjetivas, reclamando para sua efetivação a obrigatoriedade da argumentação, tendo por base as normas de um ordenamento jurídico e a obrigatoriedade de decisão pelo Estado para todo conflito intersubjetivo apresentado. A segunda postura é comprometida obliquamente com os conflitos e revela-se uma postura filosófica.

Neste contexto, propõem-se como metodologia hábil a decidir os conflitos intersubjetivos por meio da interpretação, o relacionamento do estudo da semiótica norma jurídica. Esse estudo tem marcante conteúdo filosófico e equivale a:

1) estudar o caminho de positivação dos valores que a sociedade quer ver realizados e sua entrada e saída no universo das práticas jurídicas;

2) descrever o sistema jurídico-operacional de realização desses valores, que reside na análise da formalização da linguagem do Direito, fazendo separar as estruturas encobertas pelos valores revelados pelo conteúdo das proposições jurídicas;

3) inquerir sobre a maneira pela qual o Direito, entendido como produção textual, compele comportamentos homogêneos, instituindo valores, ao se apreender o fenômeno jurídico em sua estrutura regular de apresentação, os signos.

A proposta de sistematização de um estudo da interpretação jurídica que considere esses diversos campos de pesquisa não deve conduzir a uma fragmentação do ato interpretativo. Ao contrário, a proposta aqui apresentada é no sentido da necessária implicação dessas áreas de conhecimento, visando uma interpretação totalizadora.

\section{Análise dos planos semântico e sintático da norma como preparação para sua análise pragmática}

Do próprio relacionamento dos signos lingüísticos componentes das normas jurídicas emanam diversas possibilidades comunicativas. A combinação dos signos faz com que haja possibilidade de transmissão de mensagens distintas, que devem ser reduzidas a 
uma única pelo intérprete. No plano semântico a tarefa, nesse sentido, é de distinguir entre os diversos significados dos signos, o significado correto. Para tal, a norma jurídica deve ser considerada expressão lingüística por meio da qual se positiva os valores que a sociedade quer realizar.

Tomando o Direito como instrumento de realização de valores, o sentido e o alcance da norma jurídica são determinados principalmente ao se percorrer o caminho da positivação dos valores, percurso durante o qual são preenchidos os núcleos significativos abstratos e gerais das normas jurídicas. Nesse íter, os valores ganham efetividade, ganham em concretude, passam da abstratividade característica de sua estrutura ôntica para a realidade das condutas humanas. Os valores admitem graus maiores e menores de realização e têm uma dimensão em profundidade ao longo da qual se percebe uma escala ontológica dos valores ${ }^{11}$. Esse é o caminho que os valores percorrem desde seu grau menos real até se projetarem concretamente na realidade, fundando-se uns nos outros de acordo com o grau de realização.

Percorrer o caminho de positivação dos valores é compreender o mecanismo da positivação de condutas que os realizem, mediante os quais as normas abstratas e gerais se projetam sobre o território das condutas intersubjetivas, organizando-as deonticamente, tudo para realizar o conteúdo dos valores que uma sociedade, historicamente dada pretende implanta. Para o intérprete, isso significa identificar o princípio maior que rege um tema a ser apreciado, descendo do mais genérico ao mais específico, até chegar à formulação da regra concreta que vai reger a espécie ${ }^{12}$.

Hartmann ${ }^{13}$ propôs uma contextualização da ontognoseologia dos valores.

Para o professor, a obrigatoriedade é da essência da estrutura do valor em sua plenitude. Ao valor já pertence por natureza um certo momento de dever ser. Mas, os valores são seres ideais de grande complexidade ôntica e somente podem ser percebidos pelo homem objetivamente conforme uma hierarquia ontológica, uma descrição objetiva da esfera axiológica. Nesse contexto, a esfera mais próxima da idealidade é fundamento da que

11 HESSEN, Johannes. Filosofia dos Valores. Coimbra: Almedina, 2001. p.58.

12 BARROSO, Luís Roberto. Interpretação e aplicação da Constituição: fundamentos de uma dogmática constitucional transformadora. 4. ed. São: Paulo: Saraiva, 2002. p. 149.

13 ADEODATO, João Maurício. Filosofia do Direito: uma crítica à verdade na ética e na ciência (através de um exame ontológico de Nicolai Hartmann). 3. ed. São Paulo: Saraiva, 2005. p. 171 e ss. 
mais se aproxima da realidade e quanto mais próxima a projeção do valor na realidade, mais clara e precisa a delimitação de seu dever-ser:

\section{VALOR EM SI \\ DEVER SER IDEAL \\ DEVER SER ATUAL \\ DEVER FAZER \\ VALOR REALIZADO}

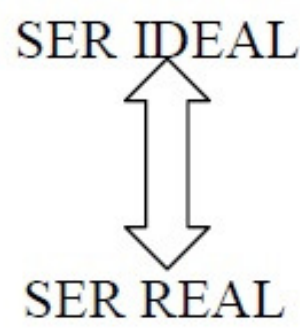

O valor em si é um conceito originário, o valor em sua plenitude, independente do real, de inatingível compreensão pelo homem. O dever ser ideal é o modo específico de ser dos valores, primeira projeção deste para a realidade e instiga atos de realização. Essa projeção do valor alberga inúmeras possibilidades de conduta. É o início da efetiva trajetória do valor na realidade e corresponde a esfera axiológica de inúmeros princípios constitucionais brasileiro. O dever ser atual é o valor já sujeito aos constrangimentos da realidade diante daquilo que é passível de realização ou não, mas ainda decorre da impossibilidade de realização plena daquilo que dever ser. O dever fazer é a parte do dever ser atual passível de realização em algumas circunstâncias reais na forma de seleção da conduta de realização de um princípio. E o valor realizado, já pertencente à esfera real nos limites de sua percepção, verte-se na conduta em si mesma, o limite objetivo da percepção do valor. Exemplificadamente, pode-se conceber essa escala ontológica:

\begin{tabular}{|c|c|}
\hline VALOR EM SI & o bem \\
\hline $\begin{array}{c}\text { DEVER SER } \\
\text { IDEAL }\end{array}$ & solidariedade (Art. 3º I, CF) \\
\hline $\begin{array}{c}\text { DEVER SER } \\
\text { ATUAL }\end{array}$ & o homem deve ajudar seu semelhante \\
\hline $\begin{array}{c}\text { DEVER } \\
\text { FAZER }\end{array}$ & o fato de alguém estar em situação de risco de vida e dever efetivamente ser \\
VAjudado
\end{tabular}


Os princípios jurídicos, positivados ou não nos textos jurídicos, devem ser considerados núcleos de significação mais genérica nos quais fluem valores. Por isso os princípios jurídicos conformam o conteúdo das normas jurídicas e de todo ordem jurídica. A proposta de Hartmann é uma sugestão para "níveis de concretude" dos valores: o caminho de positivação dos valores na realidade seria o caminho de sua positivação pelo Direito e deve ser percorrido pelo intérprete para se chegar a uma única mensagem transmitida. Para se concretizarem na realidade, os princípios jurídicos necessitam ser positivados nos textos jurídicos, num discurso normativo, o que se faz possível ao se estabelecer limites objetivos de conduta que, se praticadas, realizam estes valores.

A objetivação jurídica de valores a serem se realizados é realizada pelo Direito. A conduta humana é objeto de um juízo de valor porque faz parte do mundo do ser. "Apenas um fato da ordem do ser pode, quando comparado a uma norma, ser julgado valioso ou desvalioso, ter um valor positivo ou negativo"14 ${ }^{14} \mathrm{O}$ juízo de valor referido à conduta humana é um juízo de valor objetivo, expressa um valor constituído por meio de uma norma objetivamente válida. A autoridade jurídica prescreve uma determinada conduta humana porque considera valiosa para a comunidade dos indivíduos. Esses valores valem em relação a todas as pessoas cuja conduta é determinada como devida pela norma objetivamente válida, independente de querer ou de desejar, independente dos juízos de valores subjetivos daqueles que se submetem às normas jurídicas. Estes juízos, ao contrário dos juízos de valores objetivos, expressam o desejo ou o querer de uma ou mais pessoas, isto é, valem apenas com referência às pessoas que desejam ou querem, expressando a relação de um objeto ou conduta com desejos pessoais.

Não há como negar que a experiência jurídica é uma experiência normativa. $\mathrm{O}$ homem conduz sua vida, basicamente, baseado em regras comportamentais, notadamente regras de Direito. "O Direito constitui uma parte notável, e talvez também a mais visível, da nossa experiência normativa” ${ }^{15}$. Considerando o ponto de vista das normas jurídicas que positivam os valores desejados pelos indivíduos em sociedade, o Direito é uma ordem coativa da conduta humana. Há um especial tratamento ao comportamento humano por parte do Direito. Somente a conduta (comissiva e omissiva) do homem realizada em face de

14 KELSEN, 1998. p. 19.

15 BOBBIO, Norberto. Teoria da Norma Jurídica. Trad. Fernando Pavan Batista; Ariani Bueno Sudatti. 2. ed. Bauru: Edipro, 2003. p. 24. 
um outro é juridicamente fixada ou prevista, ou seja, considerada conteúdo de um dever jurídico. A ordem coativa em que se constitui o Direito é uma ordem psíquica. "O Direito, pela instituição de sanções, motiva os indivíduos a realizarem a conduta prescrita, na medida em que o desejo de evitar a sanção intervém como motivo na produção desta conduta" ${ }^{16} \mathrm{~A}$ sanção jurídica é institucionalizada porque a coação empreendida por ela em resposta à violação da prescrição da norma jurídica é de monopólio do Estado que determina condições sob as quais a coação deverá ser aplicada e a quem deverá ser aplicada para dar-lhe eficácia e evitar a desproporção entre violação e resposta.

No plano sintático importar ter em mente a concepção normativa da experiência jurídica, a estática jurídica remete ao estudo das normas sob seu aspecto formal, considerando sua estrutura lógico-lingüística independente de seu conteúdo. O ponto de vista formal não é o único modo de analisar a norma jurídica. Estudar a estrutura da norma jurídica sob seu aspecto lógico é uma das formas de instrumentalizar o conhecimento da experiência jurídica, forma essa que deve ser utilizada pelo intérprete do Direito, que objetiva esclarecer a significação de suas expressões. Na lógica, a linguagem é utilizada ora como ponto de apoio, ora como índice ou fim temático para poder alcançar seu objeto próprio, que é a construção de estruturas lógicas. Para a análise lógica, interessam as estruturas de linguagem que exprimam proposições, isto é, afirmações ou negações de duas idéias ou termos, por exemplo, de que tal objeto tem a propriedade tal, sendo tais proposições suscetíveis de valores (verdade / falsidade), empiricamente verificáveis.

A lógica atravessa o Direito de muitas formas. Num certo sentido, ela parece conferir-Ihe a estrutura básica, o modo pelo qual as normas se conectam no sistema do ordenamento. Em conseqüência, atinge os procedimentos interpretativos, fazendo com que a hermenêutica a ela se rendesse pelo uso preponderante dos metidos analíticos (lógicosistemático, gramatical). A norma jurídica, que deve ser construída pelo intérprete do Direito, tem a estrutura de uma proposição, vale dizer, constitui-se uma proposição jurídica.

A interpretação jurídica tem a função de construir a proposição jurídica tendo por base o texto do Direito Positivo. A norma jurídica é uma proposição que pode ser formulada a partir de enunciados diversos por meio da interpretação. Os textos normativos que são os textos positivados (textos do Direito Positivo), isto é, posto na realidade por um ato de

16 KELSEN, 1998. p. 38. 
vontade humano, na maioria dos casos a promulgação por um órgão legislativo, chamamse comumente lei. As leis são divididas em títulos, capítulos, seções, sub-seções, artigos, parágrafos, incisos, alíneas, itens. A lei positivada considerada em suas subdivisões é um enunciado e é objeto da interpretação jurídica cujo resultado final é a construção da norma jurídica concreta e individual que vale para determinados indivíduos, para um espaço fixado e um tempo marcado. É certo que o elaborador na norma jurídica, em regra, se serve da forma gramatical de um juízo, mas convém ressalvar que o seu significado é sempre uma prescrição.

Pouco importa a forma lingüística dos atos de que decorrem as normas jurídicas, o que interessa é seu sentido prescritivo. ${ }^{17}$

As normas jurídicas têm um revestimento verbal não padronizado que varia segundo o idioma, o estilo e as estruturas gramáticas. De todo modo, essa 'capa' da norma oculta o verbo deôntico dever-ser. Toda norma jurídica prescreve como deve ser o comportamento de determinados indivíduos. De forma lógica, toda norma jurídica (proposição normativa total) pode ser assim representada:

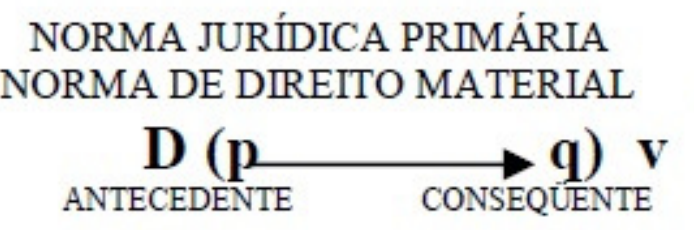

NORMA JURÍDICA PRIMÁRIA

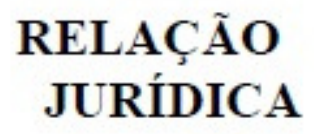

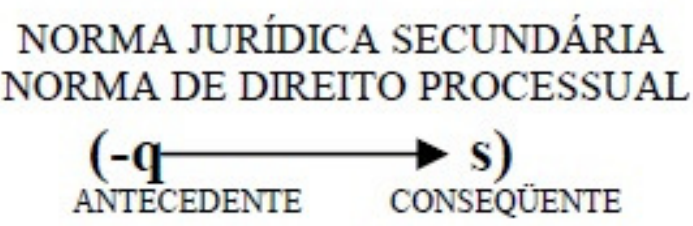

ANTIJURIDADE
SANÇÃO JURÍDICO

Na estrutura de uma norma jurídica tem-se uma hipótese legal que descreve a situação regulada e a conseqüência jurídica, que prescreve os efeitos resultantes caso se configure aquela situação, nos termos de uma atribuição de direitos e deveres. As normas, portanto, são compostas de dois elementos, um deles, descritivo, chamado dispositivo, e o outro prescritivo, chamado prescritor ou, em termos lógicos, functor, que proíbe, impõe ou permite o comportamento descrito, conferindo à norma seu caráter prescritivo, a natureza

17 DINIZ, Maria Helena. Conceito de Norma Jurídica como Problema de Essência. 3. ed. São Paulo: Saraiva, 1999. p. 72. 
de um "dever-ser". Estes elementos são ligados pela conjunção disjuntiva ou. Trata-se de uma única norma e não de duas normas e o disjuntor ou indica que tanto a prestação como a sanção têm caráter essencial na relação jurídica e na estrutura da norma: toda conduta jurídica tem de ser forçosamente lícita ou ilícita e só com a estrutura disjuntiva torna-se possível abranger ambas as possibilidades. Dado um fato temporal deve ser a prestação pelo sujeito obrigado face ao sujeito pretensor, ou, dada a não-prestação deve ser a sanção pelo funcionário obrigado face à sociedade pretensora.

Em reescritura reduzida, num corte simplificado e abstrato, a norma jurídica apresenta composição dúplice: norma primária e norma secundária. Na primeira, realizada a hipótese fática, i.e., dado um fato sobre o qual ela incide, sobrevém, pela causalidade que o ordenamento institui, o efeito, a relação jurídica com sujeitos em posições ativa e passiva, com pretensões e deveres (para nos restringirmos às relações jurídicas em sentido estrito). Na segunda, a hipótese fáctica, o pressuposto é o não-cumprimento, a inobservância do dever de prestar, positivo ou negativo, que funciona como fato jurídico (ilícito, antijurídico) fundante de outra pretensão, a de exigir coativamente perante órgão estatal a efetivação do dever constituído na norma primária. ${ }^{18}$

Fato jurídico é o antecedente da norma jurídica primária, norma que indica direitos e obrigações aos cidadãos, e descreve uma possível situação fática do mundo.

Representa um fato importante para o Direito, recolhido da realidade pela norma jurídica que a ele vincula efeitos (direitos e obrigações). "O fato recortado de entre a multiplicidade heterogênea dos fatos socioculturais (os fatos meramente físicos são qualificados valorativamente ao universo da cultura total), é, na medida em que corresponde ao esquema abstrato, o fato jurídico" ${ }^{19}$ Essa vinculação, também chamada de causalidade normativa, incidência ou juridicização é realizada pelo legislador que tem em vista os interesses da comunidade. A estrutura da proposição que se constitui logicamente uma norma jurídica é a estrutura proposicional de um hipotético condicional. Assim sendo, o antecedente é condição suficiente para determinar o conseqüente. Sem a ocorrência do fato jurídico, a relação jurídica não se concretiza. Por isso, dado um fato jurídico (antecedente = hipótese), instaurase uma relação jurídica (conseqüente = tese).

O dever-ser da norma jurídica reside no vínculo entre hipótese e tese em uma relação de implicação posta normativamente e que também obedece às leis lógicas. Uma

18 VILANOVA, Lourival. Causalidade e Relação no Direito. 4. ed. São Paulo: Revista dos Tribunais, 2000. p. 188189.

19 VILANOVA, 2000. p. 144. 
proposição não ocasiona que outra haja sem uma relação implicacional. "É a norma mesma, é o Direito Positivo que institui o relacionamento entre descritor (hipótese) e prescritor (tese) ${ }^{20 \prime \prime}$, estabelecendo o functor lógico que indica 'se se estabelecer um antecedente, a relação implicacional aponta àquele conseqüente. Assim, a formalização simbolizaria a proposição-hipótese por " $p$ " e a proposição-tese por " $q$ ", a relação implicacional por

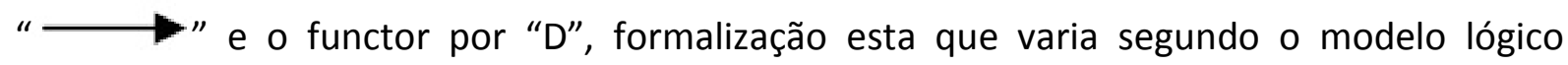
adotado.

A relação jurídica (tese) estrutura-se internamente por meio de termos, que são os sujeitos de direito e um operador que faz a função de relacioná-los intersubjetivamente.

Esse operador relaciona os sujeitos por direitos e deveres recíprocos por meio dos modais deônticos da norma jurídica (proibido, obrigatório e permitido) e traz a possibilidade de condutas humanas segundo esses modais. "O functor relacionante está compondo a conseqüência normativa, articulando um sujeito face a outro sujeito segundo as modalidades deônticas ${ }^{21 "}$.

Antijuridicidade é o descumprimento do dever jurídico, objeto da relação jurídica instaurada com a ocorrência fática da hipótese prevista como fato jurídico.

A norma jurídica total tem estrutura bimembre. Ela é formada por duas normas jurídicas de estrutura idêntica: hipótese que é condição de existência de uma tese.

Hipótese e tese fazem parte de uma relação implicacional que articula o interior de cada preposição por um modal deôntico de proibição, obrigação ou permissão.

A norma jurídica primária estatui direitos e deveres conseqüentes da verificação de pressupostos fáticos fixados na hipótese. A norma jurídica secundária pressupõe a norma jurídica primária, sendo seu conseqüente lógico. Ela preceitua as conseqüências sancionadoras quando não cumprido o que estatui a norma determinante da conduta juridicamente devida (norma primária), impondo-a coativamente ou dando-lhe conduta substitutiva reparadora. Norma primária e norma secundária são relacionadas por um conectivo lógico de antecedente lógico para conseqüente lógico. Essa relação se dá por meio do "ou" includente (v), pois ambas as normas, primária e secundária, são válidas: tanto aquela que protege bens estabelecendo condutas lícitas quanto aquela que prevê a

\footnotetext{
20 VILANOVA, Lourival. As estruturas lógicas e o sistema do Direito Positivo. São Paulo: Revista dos Tribunais, EDUC,1977. p. 53.

${ }^{21}$ VILANOVA, 1977. p. 58.
} 
realização de condutas ilícitas. "O uso sintático do ou disjuntivo assegura que, pelo menos, uma das proposições é verdadeira ou pelo menos uma é falsa, quer dizer, nunca ambas." ${ }^{22}$ Caso uma delas não seja válida, a estrutura formal da norma jurídica também não o será, inexistindo relação jurídica de imputação.

O ordenamento jurídico é um conjunto de normas que se subdivide em dois subconjuntos complementares: o subconjunto da licitude (juridicamente positiva) e o subconjunto da ilicitude (juridicamente negativa), o que, logicamente, corresponde às normas primária e secundária, respectivamente:

O conjunto que o sistema jurídico projeta, dissemos, é um conjunto cheio, repartindo-se em dois subconjuntos: um, é o da licitude, o outro é o da ilicitude. É a esse que se denomina a parte da antijuridicidade. O conjunto total compõe-se, assim, de juridicidade positiva e de juridicidade negativa. Uma não é maior nem menor que outra, pois a normatividade cobre-os exaustivamente. Também, por necessidade lógica, opõem-se em complementaridade ${ }^{23}$.

A antijuridicidade representa o antecedente lógico da proposição da norma secundária e equivale a uma conduta ilícita, é um fato antijurídico. Para o Direito, os fatos antijurídicos têm natureza jurídica diferente conforme atinjam valores mais importantes para o homem. A antijuridicidade conhecida como crime é mais grave que a contravenção, que por sua vez é mais grave que o ilícito civil, que é mais grave que uma infração.

A antijuridicidade nega a proposição implicada na norma primária (q), não ocorrendo o que nela foi preceituado. Ao negar a variável proposicional $q$, deve-se atentar para que a negação não incide na proposição da norma primária como um todo: ou a antijuridicidade vai alcançar a relação direta (prestação de $S^{\prime}$ para $S^{\prime \prime}$ ) ou irá alcançar a relação controversa (contraprestação de $S^{\prime \prime}$ para $S^{\prime}$ ).

A norma jurídica secundária também tem a estrutura de um hipotético condicional. Conseqüentemente, seu antecedente $(-q)$ é condição para determinação de seu conseqüente (s). A sanção é o conseqüente (a tese) da proposição normativa secundária, configurando a reação frente a um dever descumprido. Somente na norma secundária, que se diz norma sancionadora, o descumprimento é o pressuposto antijurídico que conduz à relação jurídica processual por meio da qual se aplica a sanção, como sanção coercitiva,

\footnotetext{
22 VILANOVA, 1977. p. 74.

23 VILANOVA, 2000. p. 301.
} 
munida da coação, não auto-aplicável pelo sujeito ativo privado de seu direito subjetivo. ${ }^{24} \mathrm{O}$ sujeito ativo é habilitado pelo direito subjetivo a obter a prestação jurisdicional do Estadojuiz, para que este aplique a coação, pois este é o órgão que tem o direito subjetivo de fazêlo.

Sendo assim, cada sanção corresponde a uma antijuridicidade. Como as antijuridicidades têm natureza jurídica diversa entre si, as sanções também se diferenciam, dependendo da antijuridicidade que se comete. Antijuridicidades penais implicam sanções penais, antijuridicidades civis, sanções civis e antijuridicidades administrativas, sanções administrativas. Mas pode uma mesma conduta antijurídica estar sujeitas a diferentes sanções, possuindo natureza jurídica múltipla, ou seja, um mesmo fato antijurídico, pode ao mesmo tempo deflagrar uma antijuricidade penal, civil e administrativa.

Apesar de se proceder a cortes metodológicos para uma proposta de sistematização do estudo da interpretação jurídica, combate-se visões unilaterais desta ciência, como a visão marxista do Direito como fato social, a visão normativista do Direito como norma ou a visão jusnaturalista do Direito como valor. Ao contrário, busca-se na complementaridade e implicação destes pontos de vista, um delineamento consistente para o ato interpretativo. A teoria tridimensional do Direito de Miguel Reale ${ }^{25}$ indica com segurança essa integração.

A visão tridimensional do Direito é uma doutrina jurídica, reflexo das influências culturais experimentadas pelo intérprete do Direito, que visa a integrar visões unilaterais do Direito, como o empirismo, o normativismo e o intelectualismo, estabelecendo vínculos entre as mesmas, numa visão unitária. A teoria tridimensional é a maneira de apresentar a experiência jurídica de forma englobante.

Reale, utilizando-se do método fenomenológico, concebe o fenômeno jurídico como realidade única de três dimensões (e não de três subdivisões): fato, valor, e norma, apreendidos como qualidades imprescindíveis de toda e qualquer experiência jurídica, como aspectos coordenados que se pressupõem quando da análise de cada qual, elementos que são vistos como termos entre si dialeticamente correlacionados. O professor relaciona a

24 VILONOVA, 2000. p. 195.

25 Retratada, em sua situação atual, principalmente em REALE, Miguel. Teoria Tridimensional do Direito. São Paulo: Saraiva, 2001. 
experiência jurídica a um caminho a se percorrer ${ }^{26}$. Esse caminho pode ser percorrido segundo três ângulos de pesquisa.

Segundo o ângulo axiológico, a norma jurídica é a indicação do caminho cujo ponto de partida é o fato rumo a determinado valor. O Direito seria a integração normativa de fatos segundo valores. Segundo a perspectiva dogmática da experiência jurídica, da integração do fato em um valor é que surge a norma e o objeto dessa experiência (da Ciência do Direito) é atingir a norma para interpretá-la e aplicá-la. Já para uma visão sociológica do fenômeno jurídico, o fato deve ser estudado segundo a norma valorada.

Pela integração dos três elementos da realidade jurídica, fato, valor e norma devem não só se relacionar, mas se dialetizar ${ }^{27}$. Com o exemplo de duas dessas perspectivas é possível demonstrar a implicação dialética necessária desses elementos. Sob a perspectiva dogmática: frente à análise dos textos do Direito Positivo, por meio de um ato interpretativo, se identifica um fato colhido da realidade social pelo Direito (fato jurídico) porque um valor que o Direito quer realizar (valor jurídico) a ele adere. Este fato valorado compõe um dos membros (o antecedente) da estrutura lógica proposicional da norma jurídica, que pode ser construída a partir da leitura dos textos normativos. A efetiva ocorrência deste fato na realidade implica a instalação de uma relação (relação jurídica) entre dois sujeitos, pelo menos, relacionados por meio de direitos e deveres recíprocos.

O tridimensionalismo de Reale, em síntese, se coaduna com a proposta aqui apresentada: uma filosofia da interpretação jurídica. Apesar da limitação dogmática que deve ser observada pelo cientista do Direito que tem a norma como um dado referencial pré-constituído (inegabilidade dos pontos de partida) posto por ato de autoridade, a atitude do intérprete é diversa; o ato interpretativo não é puramente dogmático. Quem interpreta tem que o fazer à luz dos valores desejados pela sociedade, conjugado à limitação da estrutura formal da regra jurídica positivada. "A norma jurídica marca o momento culminante da experiência do Direito, não resta dúvida, mas nem por isso deixa de ser momento ou discussão dessa realidade" ${ }^{28}$ Frente ao processo realeano de integração fáticoaxiológico de que resulta a norma jurídica, a interpretação jurídica apresenta-se como uma série de atos destinados a dar eficácia a esta, realizando comportamento.

\footnotetext{
REALE, 2001. p.118-19.

Ibid., p. 119.

28 REALE, 2002. p. 570.
} 
A interpretação jurídica não pode ser vista somente sob o ponto de vista lógico formal da concatenação lógica de preposições normativas. O intérprete baseia-se no fenômeno jurídico e o seu problema é o da atualização normativa dos valores. Como as normas jurídicas não são todo fenômeno jurídico, a Dogmática Jurídica não é toda interpretação jurídica, mas um de seus momentos.

\subsection{O plano pragmático da investigação semiótica e a atuação do intérprete sobre o produto da interpretação. Os discursos jurídicos}

A tarefa da construção da norma jurídica total percorre planos semânticos e sintáticos de investigação. Mas semântica e sintática não respondem ao questionamento sobre se a mensagem emitida por meio da linguagem jurídica é recebida e entendida pelo destinatário. Esta é a função da análise pragmática que estuda a relação existente entre os signos e as pessoas que deles se utilizam, emissor e destinatário, os intérpretes dos signos, analisando os modos de significar, que é o funcionamento da significação por meio da persuasão, legitimação ou antecipação. Os modos de significar correspondem aos usos ou funções da linguagem que, quando empregada, dependendo do contexto comunicacional, provoca uma alteração na relação designativo-denotativa dos significados das palavras ou expressões. $^{29}$

A pragmática é um dos ramos da semiótica que cuida da relação entre os signos lingüísticos e o intérprete, a conexão comunicacional intersubjetiva na qual os signos são usados. Refere-se, pois, aos problemas de argumentação, persuasão e convencimento. Sob o aspecto pragmático, interessam os efeitos interacionais que o uso da linguagem produz entre os membros de uma comunidade lingüística, vale dizer, estudam-se as relações sociais que se instauram por meio do uso da linguagem. A pragmática tenta, sem se alocar em posição secundária ou subsidiária, ocupar, no contexto interpretativo, o espaço vazio deixado pelas análises semântica e sintática da comunicação verbal.

$\mathrm{Na}$ interpretação do texto jurídico, a investigação que se denomina consistência interna do texto é o ponto de partida indispensável e é o que se reconhece primariamente. Mas não deve ser dispensada posterior investigação sobre a pertinência do alcance da

29 WARAT, 1980. p. 46. 
interpretação na perspectiva da aplicação, ou seja, saber se é possível obter o resultado que se deseja com a interpretação por meio de uma pesquisa predominantemente semântica ou sintática ou se há necessidade de uma investigação de ordem pragmática. Esta última ordem de investigação não serve para se obter o "produto da interpretação", ou seja, não contribui para a construção da norma jurídica. A pragmática age sobre o produto da interpretação, inquirindo se o mesmo é capaz de significar e comunicar. Das semelhanças entre Direito, sob o panorama dogmático e concebido como um corpo de linguagem, e linguagem, aquele deve ser avaliado pelo seu uso como linguagem, recusando-se separação estanque entre semântica, sintática e pragmática.

No plano pragmático, investiga-se se a linguagem jurídica é recebida e entendida pelo destinatário na relação estabelecida entre signos lingüísticos e intérprete, ou seja, investiga-se a conexão comunicacional intersubjetiva na qual os signos são usados. Os signos, unidades por meio das quais se constrói a norma jurídica, pretendem a comunicação. No campo jurídico, a comunicação acontece em diferentes planos porque, sob o panorama dogmático, o fenômeno jurídico s e constitui em diversas camadas lingüísticas. Cada corpo de linguagem se comunica tendo por destinatário alvos diferentes, formando discursos diversos.

O discurso do legislador ou discurso normativo pretende comunicar aos órgãos do Estado e aos indivíduos, estabelecendo diretrizes comportamentais e comunicar a reação da autoridade competente frente à reação negativa dos endereçados da comunicação anteriormente citada, estabelecendo sanções. Nesta última mensagem transmitida, estabelece-se uma relação tríade, de três comunicadores: dois que comumente são capazes de emitir e receber mensagens (legislador / órgãos do Estado e indivíduos) e um terceiro que tem a função de estabilizar os conflitos que surgem entre os dois primeiros.

É um discurso monológico, pois o receptor da mensagem empreendida não está apto a intervir em relação à exposição do emissor ou não tem interesse para tal; o receptor existe, mas ocupa posição passiva. "A manifestação do texto normativo, portanto, apresenta respostas, trazendo em si uma opção que, desde sua positivação, torna-se única, impondose como elemento determinante para decisões jurídicas sobre o fenômeno regulamentado para as condutas humanas (...)" ${ }^{30}$

30 BITTAR, Eduardo Carlos Bianca. Linguagem Jurídica. São Paulo: Saraiva, 2001. p. 193. 
Apesar da posição passiva do receptor, o emissor não fixa unilateralmente a estrutura do discurso porque, por seu discurso provocar reações no receptor, que nesse tipo de discurso se limita a admitir ou não as propostas do emissor, ele é forçado a apresentar suas propostas cuidadosamente ${ }^{31}$, isto é, atentar para como se diz para além do que se diz. $\mathrm{Na}$ análise do discurso normativo, acentua-se o papel desempenhado pela sintática, em contraposição ao papel que desempenha a semântica e a pragmática.

As normas jurídicas estabelecem um cometimento específico em relação a outra, controlando-lhe as possíveis reações. ${ }^{32}$ A comunicação realizada pela norma jurídica ao mesmo tempo em que diz como algo é ou está, apelando ao entendimento de alguém, dá uma ordem impondo um comportamento. A mensagem da norma jurídica também comunica a reação a autoridade frente à reação do endereçado de sua mensagem, estabelecendo sanções e sanções premiais. Apreende-se que, por esta previsão, o editor normativo afirma sua posição de autoridade ao mesmo tempo em que restringe a reação do endereçado do relato normativo a duas possibilidades, excluindo a alternativa do comportamento alheio a este relato.

A normas jurídicas válidas num dado tempo e lugar compõem um conjunto denominado Direito Positivo, que desempenha função de objeto a ser descrito (linguagemobjeto). Quando o Direito Positivo é captado pela função que desempenha no contexto, numa situação dada, a norma jurídica deve ser encarada sob outra perspectiva. Como instrumento de controle de conduta que, para tal, precisa controlar as relações de comunicação entre os destinatários, considerados em uma relação intersubjetiva, figura um terceiro interlocutor que guia o intérprete para o ato decisório de solucionar situações conflitivas entre os indivíduos, porque a mensagem que comunica é carregada de coatividade, o fator que controla o comportamento desses indivíduos.

Ao descrever um rol de comportamentos considerados perturbadores da ordem jurídica e, portanto, da ordem social (realizadores de um desvalor), o dispositivo legal em tela relaciona de modo implicacional uma atuação estatal coativa no caso de seu cometimento, que constitui a sanção. A sanção é o fator que controlará o comportamento

31 FERRAZ JR., Tércio Sampaio, Direito, Retórica e Comunicação: subsídios para uma pragmática do discurso jurídico. São Paulo: Saraiva, 1973. p. 26.

32 FERRAZ JR. Tércio Sampaio. Teoria da norma jurídica: um modelo pragmático. In A norma jurídica (coord. Sérgio Ferraz). Rio de Janeiro: Freitas Bastos, 1980. p. 14. 
do sujeito em uma relação intersubjetiva numa possível situação de conflito. A sanção, juntamente com o ordenamento jurídico como um todo que lhe garante a aplicação, faz emergir do texto normativo sua prescritividade na forma de indicar o poder que se esconde por trás do texto, causando o temor do descumprimento. A coação jurídica é um poder jurídico que a ordem jurídica detém, dada pelas justificativas de manutenção dessa ordem, da necessidade de controle da vida social, da solução de conflitos e da sustentação de um sistema.

Com isso, a ação lingüística do comunicador normativo toma um caráter peculiar no sentido de que, dirigindo-se a um conflito entre as partes, torna irrelevante as expectativas dos endereçados perante a sua própria expectativa. Sua decisão passa a valer independentemente de as expectativas dos endereçados serem contrárias. Ele ocupa uma posição hierarquicamente superior a dos outros dois comunicadores, na medida em que ele apenas emite a mensagem tornando os outros dois meros receptores, o que não significa que vão se apresentar absolutamente passivos, mas necessariamente não atuam como emissores de mensagem na relação comunicacional estabelecida.

Um dos objetivos do intérprete do Direito é descrever de forma metalingüística as prescrições contidas nas normas jurídicas. Pautando-se na linguagem-objeto das normas jurídicas, analisa o texto do Direito Positivo como forma de estabelecer critérios para sua atividade posterior de construir decisões jurídicas. Está análise é uma forma de discurso e conceber a Ciência do Direito como um discurso é captá-la na própria experiência discursiva de orador e ouvinte. Enquanto dotado (ou tendente a estar dotado) de cientificidade, o discurso científico percorre o caminho do rigorismo, da depuração lingüística e método adequado para se apresentar como um saber com poder de persuasão.

O discurso científico é um discurso dialógico em que orador e ouvinte assumem posições semelhantes no sentido de que precisam considerar a sua posição e a posição do outro sujeito do discurso. O ouvinte está habilitado para intervir e não assiste simplesmente a discussão e o orador não é necessariamente aquele que abre a discussão, o proponente, é partícipe, interfere na discussão e sofre as conseqüências de sua própria ação lingüística. Nesse sentido, ambos os sujeitos do discurso têm que por à prova sua autoridade sustentado por sua ação lingüística porque não há consenso, há conflito frente a alternativas. 
Toda ciência busca a verdade. A Ciência do Direito não foge a esta regra, quer atribuir o status de verdade às considerações que faz sobre o texto do Direito Positivo. Mas, à Ciência do Direito em particular, o discurso científico apresenta duas peculiaridades: i) não se utiliza de demonstrações empiricamente demonstráveis para alcançar a verdade, mas a persuasão. São os argumentos trazidos pelos discursos científico-jurídico que convencerão os receptores de sua mensagem sobre sua veracidade; ii) a verdade só é o fim último do discurso científico-jurídico quando realizado pelo sujeito-cientista não intérprete. Sempre que este utiliza o discurso científico o faz como premissa necessária para o desenvolvimento de um discurso decisório que tem por fim último a solução de um conflito. A verdade proporcionada pelo discurso da Ciência do Direito bem avaliado e interpretado (aceitação da tese exposta) é instrumento de persuasão na empreitada que o intérprete tem ao emitir seu discurso decisório.

O discurso da Ciência do Direito delineia-se um conjunto de regras para uma decisão possível de acordo com as condições de decidibilidade estabelecidas pela relação entre hipótese de conflito e hipótese de decisão. Mas, enquanto dirigido à decisão, não chega a ser discurso científico propriamente dito, mas discurso-pressuposto de um discurso decisório. Esse discurso ganha status de cientificidade quando obtém ações linguísticas independentes da situação comunicativa particular, evidenciando-se e fazendo-se compreender para qualquer especializado na área técnica, uma teoria jurídica, passando do discurso em direção ao conhecimento para o discurso destinado à transmissão de conhecimento.

Mas o discurso do intérprete do direito precisa chegar a uma decisão jurídica para ser capaz de solucionar conflitos. Para isso, precisa ser aderido por aqueles que intentam submeter, buscando convencê-los por meio da demonstração da verdade. O destinatário específico desse discurso são os sujeitos que se submeterem a uma decisão, em suma, o ser humano que se relaciona com outro, entra em conflito, cria normas para solucioná-lo e decide. O discurso do intérprete do Direito visa a solucionar um conflito de incompatibilidade entre as partes que pedem uma situação de apaziguamento, representada pela decisão.

A norma jurídica abstrata e geral, ao mesmo tempo em que a necessidade de apreensão de seu significado abre espaços à interpretação divergentes, garante a tomada de 
decisões necessárias, estabelecendo pré-decisões, cuja função é determinar outras decisões e estabelecendo como essas pré-decisões devem ser entendidas pelo endereçado (cometimento). A decisão jurídica estabelecida por uma norma jurídica concreta e individual (sentenças, acórdãos etc) não termina um conflito, mas impede sua continuação, solucionando-o de forma que ele não possa se mais levantado. A decisão soluciona a questão sem eliminá-la, tornando-a decidível. Não há eliminação de conflito, mas uma transformação: as opções não escolhidas são tidas como superadas. O discurso decisório é um discurso, a um só tempo, de um lado, derivado do discurso normativo, pois nele se sustenta, tendo por função básica sua individualização e sua concretização e tornando realidade ativa e individualizada aquilo que se encontra apenas em hipótese de dever-ser na norma.

O conflito é conseqüência natural das situações comunicativas. Ele pode se dar quando quem transmite a mensagem recusa-se a transmitir a quem a espera ou quando quem recebe a mensagem recusa-se a recebê-la de quem a transmite. Havendo possibilidade de exigência de emissão ou recebimento de mensagem, o conflito instalado reclama por uma solução, por uma decisão. A possibilidade de exigência não é uma expressão subjetiva dos comunicadores, mas submete-se à coordenação objetiva de um terceiro comunicador institucionalizado.

Este terceiro tem poder de controle, que no discurso jurídico é implementado tendo em vista a obediência e a conformidade à lei. Este poder pode ser exercido de duas maneira: 1) com base em instrumentos que o sistema normativo oferece para o disciplinamento de condutas, ou aplicação do Direito, em que se tem qualificação jurídica de fatos (situação jurídica) para acoplamento dos mesmos a textos normativos (dever-ser normativo); 2) com base em instrumentos que a retórica jurídica traz para o sistema ou argumentação jurídica que reúne os aspectos que emergem do meio circundante e repercutem no sistema.

Neste sentido, ressalta-se a importância dos aspectos pragmáticos da linguagem jurídica diante dos textos normativos a serem interpretados, tornando-se necessário o recurso à argumentação enquanto raciocínio que visa à aplicação das normas jurídicas aos casos concretos, em qualquer das duas hipóteses acima descritas. A diferença está somente 
na relação da técnica com o sistema. No entanto, interessa aqui a segunda forma, já que a primeira já fora discutida ao longo dos capítulos anteriores.

A decisão constitui um discurso dirigido ao atendimento de alguém, os destinatários da norma. Estes, para se submeterem à determinação da decisão, exigem fundamentação ou comprovação que tem a função de proporcionarem a credibilidade dos pontos de vista arrolados. O intérprete do direito, em suma, deve estar permanentemente construindo argumentos com vistas a convencer os seus interlocutores de alguma coisa. ${ }^{33} \mathrm{~A}$ argumentação constitui-se em raciocínios persuasivos que não atinge uma universalidade de demonstração, não se reduz à evidência (capaz de levar o pensamento humano a ceder), mas que requer técnicas capazes de provocar o acatamento de teses pelo homem. ${ }^{34}$

A argumentação no Direito pressupõe a articulação de um discurso com vistas a persuadir o órgão responsável pela decisão ou ainda o órgão responsável por eventual revisão da decisão a aderir à interpretação que se quer ter como vinculante para o caso concreto, mostrando que a decisão é correta ou aceitável (é justificada) Os aspectos pragmáticos da linguagem neste particular intentam, fazer prevalecer uma determinada interpretação, utilizando-se não só da função descritiva da linguagem, mas fazendo surgir explicitamente as funções expressivas e prescritivas.

O objetivo final da interpretação jurídica é enquadrar certo estado de coisas ou certa conduta humana na hipótese legal abstrata e potencial. Portanto, o intérprete realiza um tipo de paráfrase do texto normativo, elaborando sobre o mesmo um enunciado em termos mais expressivos e motivadores para provocar nos receptores da mensagem que produz um sugestionamento, aumentando a eficácia comunicativa por um recurso retórico. ${ }^{35}$ Cada intérprete, com o objetivo de convencer os destinatários de seu discurso valorizam aspectos diferentes do discurso normativo, de acordo com as inúmeras possibilidades de sentido encobertas pelo suporte lingüístico da norma.

33 COELHO, Fábio Ulhôa. Lógica Jurídica. Uma Introdução. Um Ensaio sobre a Logicidade do Direito. São Paulo: EDUC, 1992.

34 FERRAZ JR., 2001. p. 319.

35 GUERRA FILHO, Willis Santiago. Introdução a uma hermenêutica pragmática do discurso normativo. In: Estudos Jurídicos (Direito Civil, Teoria do Direito). Fortaleza: IOGE, 1985. p. 71. 


\section{Conclusão}

O fato de o homem orientar seu comportamento de acordo com normas jurídicas configura o que se denomina fenômeno jurídico que é objeto de estudo de vários ramos do conhecimento. A Ciência Jurídica realiza o estudo do fenômeno jurídico sob o ponto de vista dogmático. O Direito, sob o panorama dogmático, pode ser concebido como um corpo de linguagem composto de camadas lingüísticas que desempenham função de linguagemobjeto e metalinguagem. A Ciência do Direito é metalinguagem da linguagem-objeto que é o Direito Positivo.

Ciência do Direito e Interpretação Jurídica são ciências complementares, com propostas investigativas distintas, mas que comungam do objeto de estudo, o Direito Positivo. Para se interpretar o Direito é preciso sistematizar o texto do Direito Positivo, tarefa realizada pela Ciência do Direito. Deve a Interpretação do Direito proceder à análise da norma jurídica sob o ponto de vista semântico, sintático e pragmático. Por isso a tarefa de esclarecer o significado das normas jurídicas vai além da conjugação de métodos de interpretação oferecidos Hermenêutica Jurídica. A tarefa da interpretação é um ato complexo que deve ser praticado pelo jurista em uma postura dogmática aliada a uma postura não-dogmática.

Sob o ponto de vista semântico a análise da norma jurídica deve considerar que ela é um instrumento de positivação de valores, sendo o Direito é a via por meio da qual se identifica o conjunto de valores que a sociedade quer preservar. O Direito busca a realização de valores desejados pela sociedade. Estes valores são positivados por meio de normas, as quais interferem nas condutas humanas de forma que estes sejam realizados. A norma jurídica fixa objetivamente uma conduta como devida e funciona como medida de valor relativamente a esta conduta. A experiência jurídica é uma experiência normativa. A norma é dirigida a uma pessoa, estatuindo como devida determinada conduta de (um) ser(es) humano(s). O Direito reage contra situações e condutas humanas consideradas indesejáveis, violadoras de valores que protege.

Enquanto conjunto de normas válidas num determinado tempo e um determinado local (sob o ponto de vista dogmático), o Direito pode ser concebido sob o ponto de vista estático, por meio do qual se analisa a estrutura na norma jurídica. Pode-se contemplar o valor na estrutura lógica desta norma jurídica. A teoria tridimensional do Direito contempla 204

Revista de Direito Público, Londrina, v. 1, N. 2, P. 179-208, MAio/Ago. 2006. 
esta visão de uma interpretação filosófica do Direito, propondo um processo de integração fático-axiológico de que resulta a norma jurídica.

Em quaisquer níveis de investigação, o Direito, sob o ponto de vista dogmático, precisa da linguagem para existir porque o objeto de origem de investigação acerca do fenômeno jurídico, o Direito Positivo, se exterioriza pela linguagem. O relacionamento que identifica o Direito à linguagem acata que o fenômeno jurídico tem um sentido comunicacional. Interpretar é atribuir um certo sentido a um signo que provém de um emissor (no caso da lei, o legislador) e dirige-se aos receptores (os órgãos do Estado e os indivíduos subordinados às prescrições do ordenamento jurídico), veiculando uma informação. Para a semiótica, a interpretação deve ser concebida como parte integrante da formação de um discurso apto a atingir seu objetivo final que é decisão de conflitos.

As expressões do Direito, manifestadas por signos, compõem uma determina linguagem específica, a linguagem jurídica, dotada de regras e especificidades. próprias. Como a generalidade das linguagens, a linguagem jurídica pretende a comunicação. No campo jurídico a comunicação acontece em diferentes planos porque o fenômeno jurídico se constitui em diversas camadas lingüísticas. Cada corpo de linguagem do Direito se comunica tendo por destinatários alvos diferentes, organizadas por regras de linguagem distintas. É nesse sentido que se configuram discursos normativo, científico e decisório.

O intérprete do direito é destinatário do discurso normativo e emissor dos discursos científico e decisório, que compõem o discurso do intérprete do Direito. O discurso científico-jurídico não atende completamente as solicitações a que está adstrito o intérprete do direito, isto é, pôr fim a conflitos entre os indivíduos. Os intérpretes, no manejar do texto do Direito Positivo, precisam dirimir as adversidades do relacionamento intersubjetivo de forma conclusiva. Para tanto, também o intérprete/ aplicador do Direito empreende um discurso decisório.

\section{Referências}

ADEODATO, João Maurício. Filosofia do Direito: uma crítica à verdade na ética e na ciência (através de um exame ontológico de Nicolai Hartmann). 3. ed. São Paulo: Saraiva, 2005.

BARROSO, Luís Roberto. Interpretação e aplicação da Constituição: fundamentos de uma dogmática constitucional transformadora. 4. ed. São: Paulo: Saraiva, 2002. 
BITTAR, Eduardo Carlos Bianca. Linguagem Jurídica. São Paulo: Saraiva, 2001.

BOBBIO, Norberto. Teoria da Norma Jurídica. Trad. Fernando Pavan Batista; Ariani Bueno Sudatti. 2. ed. Bauru: Edipro, 2003.

CARVALHO, Paulo de Barros. Curso de Direito Tributário. 16. ed. São Paulo: Saraiva, 2004.

COELHO, Fábio Ulhôa. Lógica Jurídica. Uma Introdução. Um Ensaio sobre a Logicidade do Direito. São Paulo: EDUC, 1992.

DINIZ, Maria Helena. Conceito de Norma Jurídica como Problema de Essência. 3. ed. São Paulo: Saraiva, 1999.

FALCÃO, Raimundo Bezerra. Hermenêutica. São Paulo: Malheiros, 2004.

FERRAZ JR. Tércio Sampaio. Direito, Retórica e Comunicação: subsídios para uma pragmática do discurso jurídico. São Paulo: Saraiva, 1973.

. Introdução ao estudo do direito: técnica, decisão, dominação. 3. ed. São Paulo: Atlas, 2001.

Teoria da norma jurídica: um modelo pragmático. In: FERRAZ, Sérgio (Coord.). A norma jurídica. Rio de Janeiro: Freitas Bastos, 1980.

GRAU, Eros Roberto, Ensaio e Discurso sobre a Interpretação/Aplicação do Direito. 3. ed. São Paulo: Malheiros. 2005.

GUERRA FILHO, Willis Santiago. Introdução a uma hermenêutica pragmática do discurso normativo. In: Estudos Jurídicos (Direito Civil, Teoria do Direito). Fortaleza: IOGE, 1985. p. 5678.

HESSEN, Johannes. Filosofia dos Valores. Coimbra: Almedina, 2001.

KELSEN, Hans. Teoria Pura do Direito. 6. ed. Trad. João Batista Machado. São Paulo: Martins Fontes, 1998.

MAXIMILIANO, Carlos. Hermenêutica e Aplicação do Direito. 19. ed. Rio de Janeiro: Forense, 2001.

REALE, Miguel. Teoria Tridimensional do Direito. São Paulo: Saraiva, 2001. 
VILANOVA, Lourival. As estruturas lógicas e o sistema do Direito Positivo. São Paulo: Revista dos Tribunais, EDUC,1977.

. Causalidade e Relação no Direito. 4. ed. São Paulo: Revista dos Tribunais, 2000.

WARAT, Luiz. O Direito e sua Linguagem. 2a versão. Porto Alegre: Sergio Antônio Fabris Editor, 1984. 
Revista de Direito Público, Londrina, v. 1, N. 2, P. 179-208, MAio/Ago. 2006. 